\title{
Microcarrier Culture of Lepidopteran Cell Lines: Implications for Growth and Recombinant Protein Production
}

\author{
Laertis I konomou, J J ean-Christophe Drugmand, ${ }^{\dagger}$ Georges Bastin, ${ }^{\ddagger}$ \\ Yves-J acques Schneider, $§$ and Spiros N. Agathos*,t
}

Unit of Bioengineering, Place Croix du Sud 2/19, Centre for Systems Engineering and Applied Mechanics, Av. George Lemaître 4, and Laboratory of Cell Biochemistry, Place L. Pasteur 1, Cell Bioengineering Group, University of Louvain, B-1348 Louvain-la-Neuve, Belgium

\begin{abstract}
Several microcarrier systems were screened with Sf-9 and High-Five cell lines as to their ability to support cell growth and recombinant ( $\beta$-galactosidase) protein production. Growth of both cell lines on compact microcarriers, such as Cytodex-1 and glass beads, was minimal, as cells detached easily from the microcarrier surface and grew as single cells in the medium. Cell growth was also problematic on Cytopore-1 and -2 porous microcarriers. Cells remained attached for several days inside the microcarrier pores, but no cell division and proliferation were observed. On the contrary, insect cells grew well in the interior of Fibra-Cel disks mainly as aggregates at points of fiber intersection, reaching final (plateau) densities of about $4 \times 10^{6}(\mathrm{Sf}-9)$ and $2.7 \times$ $10^{6}$ (High-Five) cells $\mathrm{mL}^{-1}\left(8 \times 10^{6}\right.$ and $5.5 \times 10^{6}$ cells per $\mathrm{cm}^{2}$ of projected disk area, respectively). Their growth was described well by the logistic equation, which takes into account possible inhibition effects. $\beta$-Galactosi dase ( $\beta$-gal) production of Sf-9 cells on Fibra-Cel disks (infected at $3.3 \times 10^{6}$ cells $\mathrm{mL}^{-1}$ ) was prolonged (192 h), and specific protein production was similar to that of high-density free cell infection. Cultispher-S microcarriers were found to be a very efficient system for the growth of High-Five cells, whereas no growth of Sf-9 cells took place for the same system. Concentrations of about $9 \times 10^{6}$ cells $\mathrm{mL}^{-1}$ were reached within $120 \mathrm{~h}$, with cell growth in both microcarriers and aggregates, appearance of cellular bridges between microcarriers and aggregates, and eventual formation of macroaggregates incorporating several microcarriers. Specific protein productions after $\beta$-gal baculovirus infection at increasing cell concentrations were almost constant, thus leading to elevated volumetric protein production: final $\beta$-gal titers of 946,1728 , and $1484 \mathrm{U} \mathrm{mL} \mathrm{m}^{-1}$ were obtained for infection densities of $3.4,7.2$, and $8.9 \times 10^{6}$ cells $\mathrm{mL}^{-1}$, respectively.
\end{abstract}

\section{Introduction}

The increasing demand for therapeutic proteins with correct posttranslational modifications has led in the past 20 years to the elaboration of several expression systems and to significant advances in the areas of expression vectors, scale-up, and medium development (1-3). One of the most popular systems is the Baculovirus Expression Vector System (BEVS), which uses insect cells infected with a recombinant baculovirus to express abundantly recombinant proteins. Like other expression systems involving eukaryotic cells, its successful scaleup depends heavily on the use of stable, highly productive fast-growing cell lines, the minimization of various stresses in the bioreactor environment and the possibility of high-density cell culture without dramatic decrease in specific protein production $(4,5)$.

The use of microcarriers (macroporous or solid) in different bioreactor types is a good way to increase the available growth area for cells per unit of volume and to

* To whom correspondence should be addressed. Tel: +32-10473644. Fax: +32-10-473062. E-mail: agathos@gebi.ucl.ac.be.

+ Unit of Bioengineering.

₹ Centre for Systems Engineering and Applied Mechanics.

$\S$ Laboratory of Cell Biochemistry. attain some of the above goals $(6,7)$. Microcarriers are used routinely in animal cell culture for the growth of anchorage-dependent cells and are among the established technological platforms for industrial production (8). Yet, there are only sporadic reports on their use in insect cell culture mainly because of the anchorage-independent nature of most cell lines and the one-shot, lytic nature of the BEVS. This technology was first used for the largescale production of mosquito cells. Lazar et al. (9) screened several microcarriers to optimize the growth of Aedes aegypti (AA) cells and the production of arthropodborne viruses. Cylindrical cellulose-based microcarriers (DE-53) were found to provide the best substratum. On the other hand, Agathos et al. (10) obtained promising results from the scale-up point of view with another mosquito cell line (C7-10) immobilized in open-pore collagen-based supports.

A few reports exist also on the use of microcarriers for lepidopteran cell lines. Three-millimeter glass beads gave the best performance for Trichoplusia ni (T. ni) cells immobilized in a split-flow, airlift bioreactor (11). The use of collagen-coated microcarriers with $T$. ni cells in suspension culture gave good growth and levels of the expressed protein (gp105) close to those produced in other immobilization systems, such as T-flasks and roller 
bottles (12). As for attachment-independent insect cells, a Spodoptera frugiperda cell line (Sf-21) was cultured in a packed bed reactor with Fibra-Cel disks (13). Cells reached high densities by growing al ong the fibers of the disks, and $\beta$-galactosidase and wild-type baculovirus production levels were similar in serum-supplemented and serum-free media (13).

Most commonly used lepidopteran cell lines are currently being cultured in suspension (14-19). Nevertheless, the above-cited results indicate that cultivation of insect cells on microcarriers can be an attractive alternative to free cell suspension culture even for anchorageindependent cell lines. A comprehensive research on the immobilization of insect cells could identify the best substratum for the their growth and demonstrate the possible effect on protein production after infection with recombinant baculovirus. We undertook a comparative study aiming at the screening of several microcarrier types for the widely used High-Five and Sf-9 cell lines. The microcarriers tested included Cytodex-1 and glass beads (solid microcarriers), Cytopore- 1 and -2 and Cultispher-S (macroporous microcarriers), and Fibra-Cel disks (nonwoven polyester fabric). Cells grown on the microcarriers were infected at very high cell densities with a recombinant $\beta$-gal baculovirus, which resulted in high volumetric productions.

\section{Materials and Methods}

Cell Lines and Media. The Sf-9 and High-Five cells were a gift from Els Roode, Laboratory of Virology, Wageningen University, The Netherlands. The Sf-9 cells were cultured initially in Grace's medium supplemented with $10 \%$ fetal bovine serum (FBS). They were sequentially adapted to Sf-900 II serum-free medium in T-flasks and, afterward, to suspension by gradual increase of the agitation rate. Subsequent adaptation to other serumfree media was quite easy, with cells being completely adapted after two to three passages in the new medium. The High-Five cell line initially grew in aggregate form in serum-free culture. The cells were adapted to singlecell growth in suspension. The whole procedure lasted 1 month and resulted in full adaptation to single cell growth with occasional appearance of small (5-10 cells) aggregates. The maintenance conditions for the cells used in the microcarrier studies were, briefly, as follows: Sf-9 and High-Five cells were maintained in $125-\mathrm{mL}$ Erlenmeyer polycarbonate flasks with $25 \mathrm{~mL}$ liquid volume. Flasks were kept at $27{ }^{\circ} \mathrm{C}$ on an orbital shaker (model C-24, New Brunswick Scientific, Edison, NJ ) and agitated at $120-130 \mathrm{rpm}$. Cells were passaged every $3-4$ days at a density of $(2-3) \times 10^{6}$ cells $\mathrm{mL}^{-1}$. Cell counts were performed with a Neubauer improved hemocytometer, and cell viability was determined with the trypan blue exclusion method $(0.2 \% \mathrm{w} / \mathrm{v}$ final concentration).

More details on the maintenance of the cell lines, the media used, and the adaptation procedures in serum-free suspension culture can be found in ref 19. Growth and protein production studies were performed in either Insect-XPRESS (BioWhittaker Europe, Verviers, Belgium) or YPR, a new medium based on the use of yeastolate ultrafiltrate and Primatone RL and supplemented with glucose ( $55.5 \mathrm{mM}$ final concentration) and glutamine (15-17 mM final concentration) (19).

Microcarrier Systems. Solid Microcarriers. The solid supports tested included glass microcarrier beads (G-2892) and Pharmacia's Cytodex-1, both purchased from Sigma (St. Louis, MO). F or both types of mi crocarriers, stock solutions of $20 \mathrm{~g} \mathrm{~L}^{-1}$ were prepared before use. Briefly, $1 \mathrm{~g}$ of microcarriers were added in $50 \mathrm{~mL}$ of PBS (phosphate-buffered saline) in a pre-siliconized bottle and left to hydrate. The PBS was then replaced with fresh buffer, and the microcarriers were autoclaved. Stock solutions were kept at $4{ }^{\circ} \mathrm{C}$ before use. The preparation of the microcarriers for inoculation involved the removal of PBS, addition of fresh filter-sterilized medium, and soaking of the microcarriers overnight at room temperature. The inoculation step was done in onethird of the final volume over $4 \mathrm{~h}$ at $27^{\circ} \mathrm{C}$ with periodical agitation of the flasks to ensure uniform distribution of the cells. A small sample of the cell suspension was withdrawn in order to determine the seeding efficiency, and the final volume was reached with addition of fresh medium. The seeding efficiency is defined as follows:

$$
\text { seeding efficiency }=\frac{X_{0} V_{0}-X_{f} V_{f}}{X_{0} V_{0}} \times 100
$$

where $X_{0}$ and $X_{f}$ are, respectively, the viable cell concentrations for the liquid phase $\left(10^{6}\right.$ cells $\left.\mathrm{mL}^{-1}\right)$ at time 0 and at the end of inoculation and $V_{0}$ and $V_{f}$ are the liquid volumes $(\mathrm{mL})$ at time 0 and at the end of the inoculation.

Inoculation densities were $2 \times 10^{5}$ and $4 \times 10^{5}$ cells $\mathrm{mL}^{-1}$ (with respect to the final volume) for High-Five and Sf-9 cells, respectively. Microcarrier concentrations were 5 and $20 \mathrm{~g} \mathrm{~L}^{-1}$ for Cytodex-1 and glass beads, respectively.

Macroporous Mi crocarriers. Cytopore-1 and - 2 were donated to us by Amersham Phar macia Biotech Benelux (Roosendaal, The Netherlands), and Cultispher-S was a gift from Hyclone E urope (presently Perbio Science NV, Erembodegem-Aalst, Belgium). The former are DEAE ( $\mathrm{N}, \mathrm{N}$-diethylaminoethyl)-coated microcarriers based on a cross-linked cellulose matrix with a mean diameter of $230 \mu \mathrm{m}$, average pore size of $30 \mu \mathrm{m}$, and high porosity (>85\%). The latter are gelatin microcarriers with a hydrated diameter range of 130-380 $\mu \mathrm{m}$, average pore size of $20 \mu \mathrm{m}$ and porosity of about $50 \%$. The preparation of these macroporous microcarriers for cell culture was performed according to the manufacturers' instructions and was similar to that for solid microcarriers. The macroporous supports were rinsed at least once with sterile PBS and twice with medium before inoculation. Seeding densities were the same as for the solid microcarriers, and support concentration was $2 \mathrm{~g} \mathrm{~L}^{-1}$ for Cytopore-1 and -2 , and $1 \mathrm{~g} \mathrm{~L}^{-1}$ for Cultispher-S microcarriers.

Cell Growth Studies on Microcarriers. All experiments were performed in either 125 - or 250-mL polycarbonate shake-flasks (Corning, Acton, MA) agitated on an orbital shaker (model C24, New Brunswick Scientific, Edison, NJ ) at $150 \mathrm{rpm}$ unless otherwise indicated. The flasks were siliconized with Sigmacote (Sigma, St Louis, MO) and autoclaved before use. Suspension volume (with microcarriers) was one-fifth of the total flask volume to ensure good aeration and agitation of the cultures. Onemilliliter samples were withdrawn daily to measure the concentration of free and immobilized cells as well as the consumption of metabolites and the accumulation of metabolic byproducts. Microcarriers were left to settle for about $3 \mathrm{~min}$, and $100 \mu \mathrm{L}$ was withdrawn to be used for free cell count with a Neubauer hemocytometer and cell viability determination by trypan blue exclusion $(0.2 \%$ $\mathrm{w} / \mathrm{v}$ final concentration). Another $400 \mu \mathrm{L}$ of microcarrierfree supernatant was employed for metabolite analysis using a BioProfile 100 analyzer (Nova Biomedical, Waltham, MA). The rest was mixed with $400 \mu \mathrm{L}$ of orystal violet 
solution $(0.1 \% \mathrm{w} / \mathrm{v}$ in $0.1 \mathrm{M}$ citric acid) and incubated for $4 \mathrm{~h}$ at $27{ }^{\circ} \mathrm{C}$ with vigorous vortexing every $30 \mathrm{~min}$. Enumeration of nuclei was performed with a Neubauer hemocytometer, and the concentration of cells on the microcarriers was calculated by taking into account the total free cell concentration in the medium.

Protein Production Studies on Microcarriers. A recombinant AcM NPV baculovirus carrying the E. coli $\beta$-galactosidase ( $\beta$-gal) gene under the control of the polyhedrin promoter was purchased from I nvitrogen (San Diego, CA). Amplification of the virus was performed in either 100-mm Petri dishes or in shake-flasks by infecting Sf-9 cells with a MOI (multiplicity of infection) of 0.1 plaque forming units (pfu) cell ${ }^{-1}$. Virus titer was determined by the end-point dilution assay in 60-well (Terasaki) plates (Nal ge Nunc I nternational, Rochester, NY). The virus stock was diluted from $10^{-1}$ to $10^{-9} ; 90 \mu \mathrm{L}$ of each dilution was mixed with $90 \mu \mathrm{L}$ of a Sf-9 cell suspension $\left(1.5 \times 10^{6}\right.$ cells $\left.\mathrm{mL}^{-1}\right)$; and $10 \mu \mathrm{L}$ of this mixture were added to each well of the Terasaki plate (six wells per dilution). Six wells with uninfected Sf-9 served as negative control. After a 4-day incubation, $10 \mu \mathrm{L}$ of a $0.4 \%$ (w/v) Bluo-gal (Life Technologies SA, Merelbeke, Belgium) solution were added to each well. Infected wells were identified by the presence of blue color. The TCID $\mathrm{D}_{50}$ $\mathrm{mL}$ and the virus titer were calculated using standard methods (20).

Baculovirus infections of cells grown on mi crocarriers were performed in duplicate in shake-flasks with a MOI of 2. Medium change was done just before infection. Sampling ( $2 \mathrm{~mL}$ ) was performed daily. One milliliter was used for cell count as described above. The other $1 \mathrm{~mL}$ was used for the determination of $\beta$-gal in the supernatant, in the free cells, and in the immobilized cells. After sedimentation for $3 \mathrm{~min}$ to separate the microcarriers from the liquid phase, $250 \mu \mathrm{L}$ of this sample was centrifuged and the supernatant was recovered for the assay of the extracellular $\beta$-gal. One microliter of Iysis solution (1/3 v/v Triton X-100) was added to another 250 $\mu \mathrm{L}$ of the sample, and the supernatant, after removal of the cell debris, was used for the determination of the $\beta$-gal in the free cells by taking into account the result of the first measurement. Finally, $500 \mu \mathrm{L}$ of lysis solution was added to the remaining $500 \mu \mathrm{L}$ of the sample that contained the microcarriers, and the debris-free supernatant was used for the determination of the $\beta$-gal in the immobilized cells. All of the treated samples were kept at $-20^{\circ} \mathrm{C}$ until the $\beta$-galactosidase assay. The latter was a modification of Miller's method (21). Briefly, $10 \mu \mathrm{L}$ of appropriately diluted sample was mixed with $1000 \mu \mathrm{L}$ of Z-buffer in a cuvette at $37^{\circ} \mathrm{C}$. Afterward, $200 \mu \mathrm{L}$ of an ONPG solution ( $4 \mathrm{mg} \mathrm{mL}^{-1}$ in a $0.1 \mathrm{M}$ phosphate buffer) was added. The reaction was stopped after 10-15 $\mathrm{min}$ with addition of $500 \mu \mathrm{L}$ of $\mathrm{Na}_{2} \mathrm{CO}_{3}(1 \mathrm{M})$. The absorbance was measured at $420 \mathrm{~nm}$, and the concentration of the $\beta$-gal $\left(\mathrm{U} \mathrm{\textrm {mL } ^ { - 1 } )}\right.$ was calculated by using the calibration curve of a $\beta$-gal standard (X grade, G 2513, Sigma, St Louis, MO).

Growth and Protein Production Studies on FibraCel Disks. The optimized inoculation procedure for insect cells has been described elsewhere (22). Growth of both cell lines was evaluated for two different Fibra-Cel concentrations, namely, 5 and $10 \mathrm{~g} \mathrm{~L}^{-1}$, whereas disk concentration for infection studies was $10 \mathrm{~g} \mathrm{~L}^{-1}$. To determine cell numbers and $\beta$-gal concentration in the medium, samples were treated as described above for macroporous and solid microcarriers. For growth studies, three Fibra-Cel disks were removed daily from the culture flask and put in $1 \mathrm{~mL}$ of lysis solution $(0.1 \% \mathrm{w} / \mathrm{v}$ crystal violet in $0.1 \mathrm{M}$ citric acid). The released nuclei were counted after appropriate dilution with an improved Neubauer hemocytometer. To determinethe $\beta$-gal content of immobilized cells, four Fibra-Cel disks were put in lysis solution for $30 \mathrm{~min}$ and the supernatant, after centrifugation, was used as described above. The sampling of four disks per day without a proportional decrease of medium volume dictated the need for correcting the extracellular and immobilized cell $\beta$-gal concentrations. For each time point we took into account the $\beta$-gal that could have been produced by the disks that had been removed up to this time point. The corrected intracellular $\beta$-gal at time i, i.e., $\beta$-gal of cells in the Fibra-Cel disks, was simply calculated from the rule of three. The corrected extracellular $\beta$-gal at time i, i.e., $\beta$-gal in the medium, was calculated by taking into account the $\beta$-gal that would have been produced in the time interval from $\mathrm{i}-1$ to $\mathrm{i}$ by the disks removed at time $i-1$. This correction was based on the assumption that all of the disks have more or less the same productivity and is described by the following two equations:

extracellular:

$$
\beta \text {-gal }{ }_{\mathrm{i}}(\mathrm{c})=\beta \text {-gal }{ }_{\mathrm{i}}(\mathrm{m})+\frac{\left(\mathrm{N}_{\mathrm{i}-1}^{\text {disks }}-\mathrm{N}_{\mathrm{i}}^{\text {disks }}\right)}{\mathrm{N}_{\mathrm{i}}^{\text {disks }}}\left[\beta-\mathrm{gal}_{\mathrm{i}}(\mathrm{m})-\right.
$$$$
\left.\beta-\text { gal }_{i-1}(\mathrm{~m})\right]
$$

intracellular (Fibra-Cel):

$\beta-$ gal $_{\mathrm{i}}(\mathrm{c})=\beta$-gal ${ }_{\mathrm{i}}(\mathrm{m}) \times \frac{\mathrm{N}_{0}^{\text {disks }}}{\mathrm{N}_{\mathrm{i}}^{\text {disks }}}$

where $\beta$-gal ${ }_{\mathrm{i}}(\mathrm{c})$ is the corrected $\beta$-gal concentration for time i $\left(\mathrm{U} \mathrm{mL}^{-1}\right), \beta$-gal ${ }_{\mathrm{i}-1}(\mathrm{~m})$ and $\beta$-gal $\mathrm{i}_{\mathrm{i}}(\mathrm{m})$ are the measured $\beta$-gal concentrations at time i -1 and i $\left(\mathrm{U} \mathrm{mL}^{-1}\right)$, and $\mathrm{N}_{0}^{\text {disks }}, \mathrm{N}_{\mathrm{i}-1}^{\text {disks }}$, and $\mathrm{N}_{\mathrm{i}}^{\text {disks }}$ are the number of $\mathrm{Fibra}-\mathrm{Cel}$ disks at time zero, $\mathrm{i}-1$, and $\mathrm{i}$, respectively.

Analytical Methods. Metabolite concentration, $\mathrm{pH}$, and osmolality of medium samples were measured with a Bioprofile-100 analyzer (Nova Biomedicals, Waltham, MA). I mmobilized cells were observed using either phase contrast microscopy (Leitz Labovert, Leitz, Germany) or fluorescent microscopy (Labophot-2, Nikon, J apan). In the case of macroporous microcarriers we have found that addition of trypan blue dye (diluted $2 x$ ) would result, at the same time, in the coloration of dead cells and slight coloration of the microcarriers, rendering easier the examination of the immobilized cells. The fluorescent microscopy was combined with the Live/Dead cytotoxicity kit (Molecular Probes, Leiden, The Netherlands) to evaluate the viability and the distribution of cells on the microcarriers. In the case of Fibra-Cel disks where direct microscopic observation was difficult because of the disks size, confocal microscopy was employed. The system consisted of an emission source (Bio-Rad MRC 1024, BioRad, U.K.) and a mi croscope (Zeiss Axiovert 135 M, Zeiss, Germany) coupled with a col or video camera (TK-1280E, J VC, J apan) and the Confocal Assistant software. Cells were fixed with formaldehyde ( $4 \% \mathrm{v} / \mathrm{v}$ in PBS) for $30 \mathrm{~min}$ and then stained with FM 4-64 (Molecular Probes, Leiden, The Netherlands) and DAPI dyes before observation.

\section{Results}

Growth Studies on Microcarriers. A variety of microcarriers with different surface and matrix composition (Table 1) were tested with both High-Five and Sf-9 cell lines. The growth studies of insect cells on solid 
Table 1. Physical Parameters of Microcarriers Tested

\begin{tabular}{|c|c|c|c|c|c|c|c|c|c|}
\hline $\begin{array}{l}\text { microcarrier } \\
\text { name }\end{array}$ & source & $\begin{array}{c}\text { microcarrier } \\
\text { type }\end{array}$ & $\begin{array}{c}\text { matrix } \\
\text { composition }\end{array}$ & $\begin{array}{l}\text { surface } \\
\text { compo- } \\
\text { sition }\end{array}$ & $\begin{array}{c}\text { charge } \\
\text { density } \\
\left(\text { meq g }^{-1}\right)\end{array}$ & $\begin{array}{l}\text { size } \\
(\mu \mathrm{m})\end{array}$ & $\begin{array}{c}\text { density } \\
\text { (g cm }{ }^{-3} \text {, } \\
\text { in } 0.9 \% \\
\mathrm{NaCl} \text { ) }\end{array}$ & $\begin{array}{c}\text { approx area } \\
\text { (cm² } \mathrm{g}^{-1} \\
\text { dry wt) }\end{array}$ & $\begin{array}{l}\text { av pore } \\
\text { size }(\mu \mathrm{m})\end{array}$ \\
\hline glass beads & Sigma & solid & copolymer plastic & glass & & $95-150$ & 1.04 & 475 & \\
\hline Cytodex-1 & Pharmacia & solid & $\begin{array}{l}\text { cross-linked } \\
\text { dextran }\end{array}$ & DEAE & $1.4-1.6$ & $147-248$ & 1.03 & 4400 & \\
\hline Cytopore-1 & Pharmacia & macroporous & $\begin{array}{l}\text { cross-linked } \\
\text { cotton cellulose }\end{array}$ & DEAE & 1.0 & 230 & 1.03 & 11000 & 30 \\
\hline Cytopore-2 & Pharmacia & macroporous & $\begin{array}{l}\text { cross-linked } \\
\text { cotton cellulose }\end{array}$ & DEAE & 1.8 & 230 & 1.03 & 11000 & 30 \\
\hline Cultispher-S & Hyclone & macroporous & gelatin & gelatin & & $130-380$ & 1.04 & & 20 \\
\hline Fibra-Cel & $\begin{array}{l}\text { New Brunswick } \\
\text { Scientific }\end{array}$ & porous disks & $\begin{array}{l}\text { PET (polypro- } \\
\text { pylene screen) }\end{array}$ & & & $6 \mathrm{~mm}$ & 1.04 & $\sim 1200$ & $\begin{array}{l}\text { open void } \\
\text { structure }\end{array}$ \\
\hline
\end{tabular}

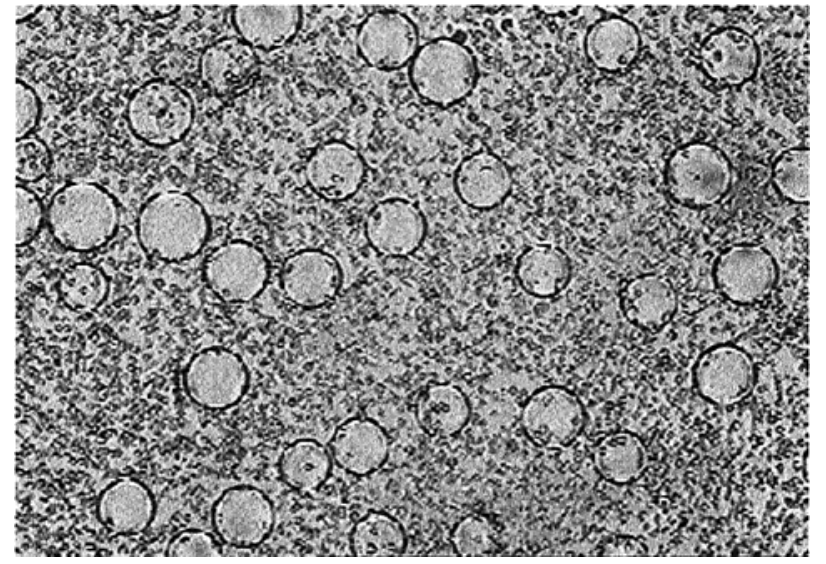

Figure 1. Sf-9 cells on Cytodex-1 microcarriers. The experiment was performed in $125-\mathrm{mL}$ shake flasks with $25-\mathrm{mL}$ liquid volume in Insect-XPRESS medium; $192 \mathrm{~h}$ postinoculation $(100 \times)$.

microcarriers gave rather disappointing results. Although seeding efficiencies were high for both microcarrier types ( $\sim 100 \%$ for Cytodex-1 and $\sim 85 \%$ for glass beads), cells detached easily from the supports during culture and grew freely in the medium (Figure 1). Thus compact microcarriers were not considered for infection studies of immobilized cells.

Growth of insect cells on Fibra-Cel disks was then evaluated in shake-flask culture. As this system is heterogeneous we chose to report cell numbers per $\mathrm{cm}^{2}$ of projected disk area and not per $\mathrm{mL}$ of medium. We had previously found that $5 \times 10^{5}$ and $7.5 \times 10^{5}$ cells $\mathrm{cm}^{-2}$ projected area, respectively, were the optimal inoculation densities for High-Five and Sf-9 cells (22). We studied the growth of insect cells at two different disk concentrations and two different agitation rates. Thus, the conditions for this study were $10 \mathrm{~g} \mathrm{~L}^{-1}, 150 \mathrm{rpm}$ and $5 \mathrm{~g} \mathrm{~L}^{-1}, 100 \mathrm{rpm}$, which will be referred to as Exp.1 and Exp.2. High-Five and Sf-9 cells after a growth phase of about 12 days reached a plateau concentration that was higher for Sf-9 cells (Figure $2 \mathrm{~A}$ and $\mathrm{B}$ ). F ree cell concentrations during cell growth on Fibra-Cel disks was very low at the beginning $\left(<10^{4}\right.$ cells $\mathrm{mL}^{-1}$ ) and between 1 and $2 \times 10^{6}$ cells $\mathrm{mL}^{-1}$ at the end of the culture. The growth of cells on the Fibra-Cel disks was found to be adequately described by the logistic equation (23), which has been previously used for modeling the growth of Sf-9 cells in suspension before the onset of decline in viable cell count (24):

$$
\frac{\mathrm{dX}}{\mathrm{dt}}=\mu \mathrm{X}(1-\beta \mathrm{X})
$$

where $X$ is the immobilized cell concentration $\left(10^{6}\right.$ cells

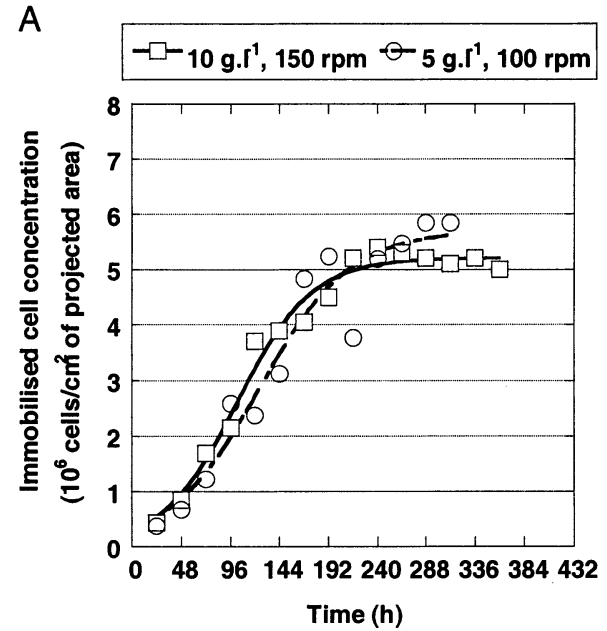

B

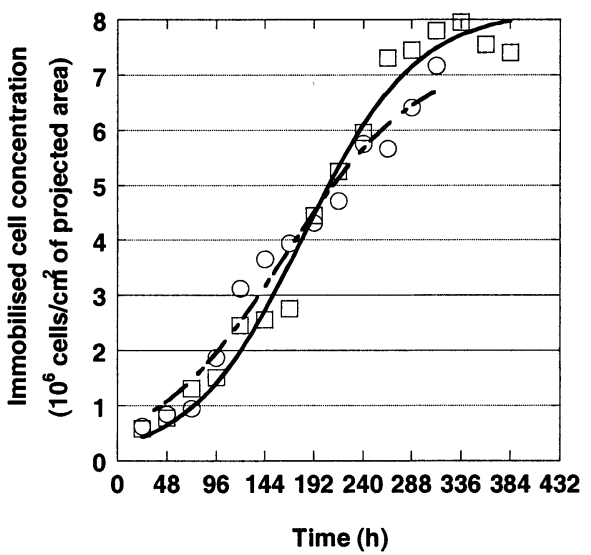

Figure 2. Growth of High-Five (A) and Sf-9 cells (B) on FibraCel disks. The experiments were performed in 250-mL shake flasks with 50-mL liquid volume in Insect-XPRESS medium. $\mathrm{Half}$ of the medium was exchanged every 2-4 days to provide enough nutrients to the cells. A total change of medium was also done once for High-Five. The conditions for Exp.1 were a disk concentration of $10 \mathrm{~g} \mathrm{~L}^{-1}$ and an agitation rate of $150 \mathrm{rpm}$, whereas for Exp. 2 the respective conditions were $5 \mathrm{~g} \mathrm{~L}^{-1}$ and $100 \mathrm{rpm}$. The model fit of cell growth according to the logistic equation is the continuous line for Exp.1 and the dashed line for Exp.2.

$\left.\mathrm{cm}^{-2}\right)$, t is the time (h), $\mu$ is the specific growth rate $\left(\mathrm{h}^{-1}\right)$, and $\beta$ is an inhibition constant that is the inverse of the maximal attained concentration on the microcarriers $\left(\mathrm{cm}^{2}\right.$ $\left.\left(10^{6} \text { cells }\right)^{-1}\right)$. Integration of eq 4 with $\mathrm{X}=\mathrm{X}_{0}$ at $\mathrm{t}=0$ gives

$$
X=\frac{X_{0} e^{u t}}{1-\beta X_{0}\left(1-e^{u t}\right)}
$$


Table 2. Kinetic Parameters of Logistic Equation for Insect Cell Growth on Fibra-Cel Disksa

\begin{tabular}{lccc}
\hline cell line and culture conditions & $\mathrm{X}_{0}\left(10^{6}\right.$ cells cm $\left.{ }^{-2}\right)$ & specific growth rate $\left(\mathrm{h}^{-1}\right)$ & $\beta\left(\mathrm{cm}^{2}\left(10^{6} \mathrm{cells}^{-1}\right)\right.$ \\
\hline Sf-9 (Exp.1) & $0.28(0.09)$ & $0.018(0.001)$ & $0.12(0.004)$ \\
Sf-9 (Exp.2) & $0.55(0.15)$ & $0.015(0.002)$ & $0.135(0.011)$ \\
High-Five (Exp.1) & $0.30(0.09)$ & $0.027(0.003)$ & 0.98 \\
High-Five (Exp.2) & $0.33(0.19)$ & $0.022(0.005)$ & $0.19(0.004)$ \\
\end{tabular}

a The conditions for Exp.1 were a disk concentration of $10 \mathrm{~g} \mathrm{~L}^{-1}$ and an agitation rate of 150 rpm whereas for Exp. 2 the respective conditions were $5 \mathrm{~g} \mathrm{~L}^{-1}$ and $100 \mathrm{rpm}$. The errors for the different calculated parameters are given in parentheses beside the respective parameter.

The equation parameters for each growth curve were calculated by use of the Kaleidagraph curve fit utility (Synergy Software, Reading, PA) and are shown in Table 2. In each case, the logistic equation fitted very well the observed cell growth on the Fibra-Cel disks (regression coefficient $>90 \%$, Table 2 ). Confocal microscopy micrographs gave interesting information on the distribution of cells inside the Fibra-Cel disks (Figure 3A and B). At $312 \mathrm{~h}$ when the plateau density had been reached (Figure $2 B$ ) the disks were not completely filled with cells (F igure 3A). In fact, cells grew as clumps, preferentially on points of fiber intersection and not across the fibers, keeping an epithelial-like morphology similar to the one observed in suspension culture (Figure 3B).

A series of macroporous microcarriers (Cytopore-1 and -2 and Cultispher-S) were also evaluated for the growth of High-Five and Sf-9 cells. Virtually no growth was observed for either High-Five (inoculation densities of 0.2 and $0.4 \times 10^{6}$ cells $\mathrm{mL}^{-1}$ ) or Sf-9 (inoculation density of $0.4 \times 10^{6}$ cells $\mathrm{mL}^{-1}$ ) on Cytopore-1. Dead cell concentration in suspension increased progressively as dead cells started to detach from the microcarriers and leak into the medium. As with Cytopore-1, total cell concentration did not exceed $0.5 \times 10^{6}$ cells $\mathrm{mL}^{-1}$ on Cytopore-2. There was no significant difference in cell growth for High-Five cells at two seeding densities $\left(0.2\right.$ and $0.4 \times 10^{6}$ cells $\mathrm{mL}^{-1}$ ) and with supplementation of the medium with $5 \%$ serum. Seeding efficiencies varied from $92 \%$ to $100 \%$ for both cell lines, suggesting that the initial phase of cell adhesion had been unproblematic. Daily microscopic examination of the Cytopore microcarriers with a phasecontrast microscope revealed that cells were immobilized in the pores of the microcarrier but they were not dividing. The possibility of a defective microcarrier lot was ruled out by seeding the microcarriers with $\mathrm{CHO}$ $\mathrm{K} 1$ cells and cultivating in BDM basal medium (25) supplemented with $5 \%$ serum. $\mathrm{CHO}$ cells reached $2.5 \times$ $10^{6}$ cells $\mathrm{mL}^{-1}$ at $96 \mathrm{~h}$ while being inoculated at $0.2 \times$ $10^{6}$ cells $\mathrm{mL}^{-1}$. Because of the poor growth of insect cells on both types of Cytopore, we did not consider this microcarrier for infection studies.

A type of gelatin carrier, the Cultispher-S microcarriers (26), was al so tested with insect cells in agitated culture. Sf-9 cells did not grow well on this type of support, reaching a final density of about $0.5 \times 10^{6}$ cells $\mathrm{mL}^{-1}$ (data not shown). As for the attached cell concentration of High-Five cells, it remained relatively stable during the first $240 \mathrm{~h}$ at about $1 \times 10^{6}$ cells $\mathrm{mL}^{-1}$ (Figure 4A). Cells grew primarily in the pores near the microcarrier surface and clumps of cells protruded from the microcarrier (Figure 3C). On the contrary, free cell concentration varied as a result of the medium change and passed through a maximum of about $4 \times 10^{6}$ cells $\mathrm{mL}^{-1}$ at 144 h (Figure 4A). Aggregated cells appeared in the medium as early as $96 \mathrm{~h}$, but we tried to disperse them by gentle pipetting. The dispersion of cell clumps and microcarrier aggregates continued until $240 \mathrm{~h}$. The unobstructed formation of aggregates and cellular bridges between mi crocarriers and aggregates (Figure 3D) resulted in the formation of macroaggregates that incorporated several microcarriers (Figure 3E). The viability was high inside these macroaggregates, as can be seen in Figure $3 \mathrm{E}$. This phenomenon coincided with an increase of attached cell concentration that rapidly exceeded $6 \times 10^{6}$ cells $\mathrm{mL}^{-1}$. The total cell concentration at the end of the fed-batch culture was above $10 \times 10^{6}$ cells $\mathrm{mL}^{-1}$ with $80-85 \%$ viability. To verify that the formation of macroaggregates was necessary for achieving a high attached cell concentration, the experiment was repeated without dispersing any aggregates formed (Figure 4B). High-Five cells grew rapidly and reached a total viable cell concentration of $10 \times 10^{6}$ cells $\mathrm{mL}^{-1}$ within $120 \mathrm{~h}$, out of which $7.5 \times 10^{6}$ cells $\mathrm{mL}^{-1}$ represented cells growing in aggregates, microcarriers, or macroaggregates incorporating microcarriers (Figure 4B).

Infection Studies on Fibra-Cel Disks and Cultispher-S Microcarriers. The screening of several types of microcarriers for the growth of the two cell lines resulted in the selection of two immobilization systems, namely, the Fibra-Cel disks for Sf-9 cells and the Cultispher-S microcarriers for the High-Five cells. Both systems ensured a high and sustained cell concentration with high viability when employed in fed-batch culture. The effect of the cell immobilization and very high local cell concentrations (aggregates inside the Fibra-Cel disks and macroaggregates on, in, and around Cultispher-S carriers) on recombinant protein production was investigated by infecting growing immobilized cells with a recombinant baculovirus expressing $\beta$-gal (F igures 5 and 6). Sf-9 cells were al lowed to grow on the Fibra-Cel disks to a density of $6.6 \times 10^{6}$ cells $\mathrm{cm}^{-2}$ (corresponding to a concentration of $3.3 \times 10^{6}$ cells $\mathrm{mL}^{-1}$ ), and they were subsequently infected with a $\mathrm{MOl}$ of 2. Production of $\beta$-gal was prolonged compared to that of cells infected in suspension (data not shown) and peaked at $192 \mathrm{~h}$ postinfection, with a $\beta$-gal concentration of about $620 \mathrm{U}$ $\mathrm{mL}^{-1}$ (Figure 5). As can be seen from this figure, at almost any time point after infection, extracellular $\beta$-gal made up for at least $75 \%$ of the total $\beta$-gal. This fact combined with the low $\beta$-gal content of free cells suggest that $\beta$-gal in the medium was coming primarily from immobilized cells that were either lysed or had compromised membranes. Although specific protein production was lower for the infection on the Fibra-Cel disks compared to that of a low-density infection of suspension cells it was similar to the one from a similar high-density infection (Table 3).

High-Five cells growing on Cultispher-S microcarriers were infected at three viable cell concentrations, namely, $3.4,7.2$, and $8.9 \times 10^{6}$ cells $\mathrm{mL}^{-1}$ with a $\mathrm{MOI}$ of 2 (Figures 6 and 7). Almost all of the cells were growing on the microcarriers and/or in aggregates at the time of infection for the first two densities (Figure 7A and B). Infection led to the increase of free cell concentration (more pronounced in the case of the first infection density) and extended cell lysis by $96 \mathrm{~h}$ postinfection (p.i.) (Figure 7A and $B$ ). Maximal protein volumetric production doubled when infection density was increased from 3.4 to $7.2 \times$ 

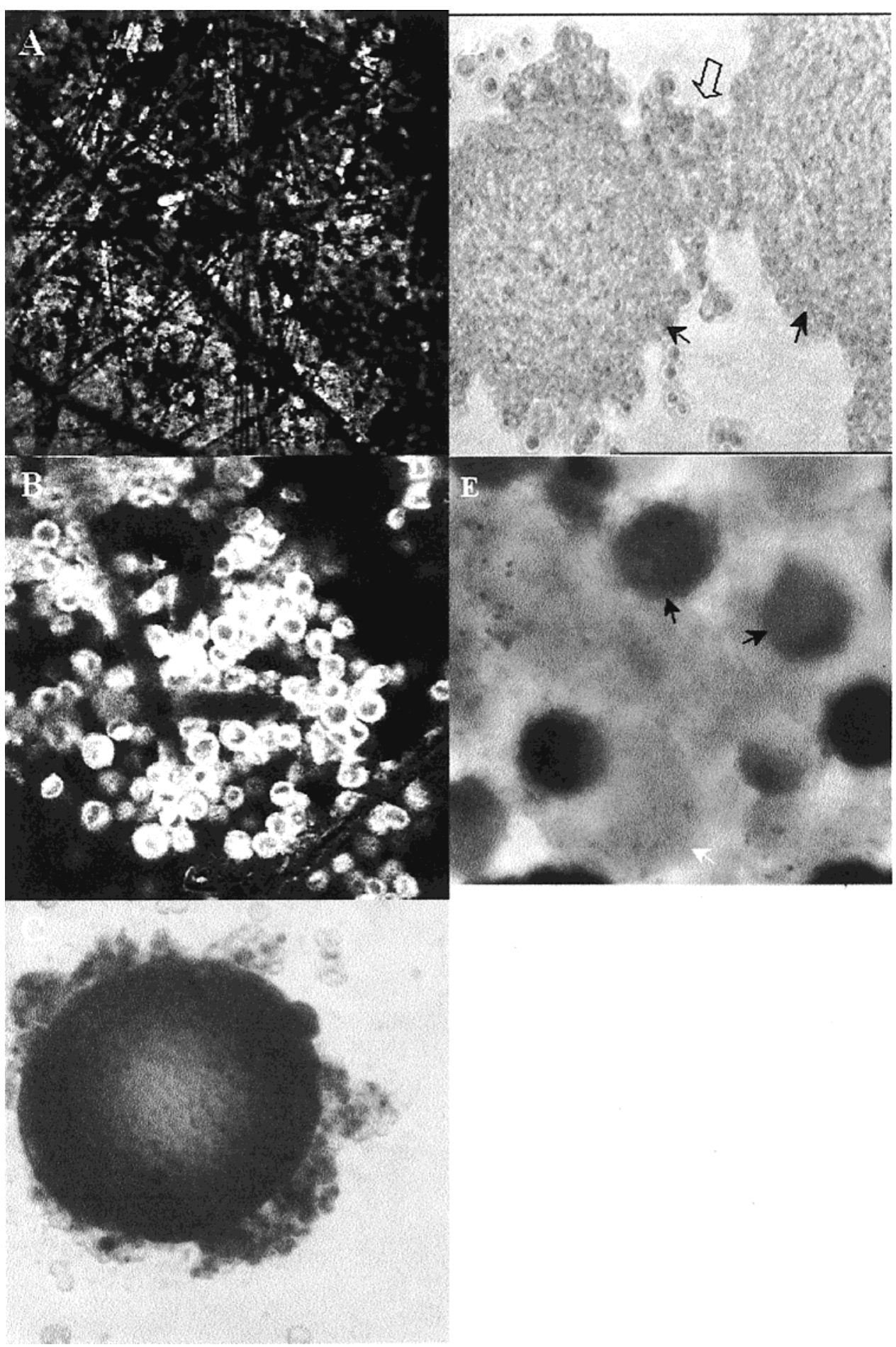

Figure 3. Confocal microscopy photos of (A) Sf-9 cells growing on the surface of a Fibra-Cel disk ( $312 \mathrm{~h}$ of culture) as seen from the interior $(100 \times)$ and (B) formation of Sf-9 aggregates on a fiber intersection inside a Fibra-Cel disk (600x). (C) High-Five cells growing on the surface of a Cultispher-S microcarrier at $168 \mathrm{~h}(250 \times)$. (D) Formation of cellular bridges between Cultispher-S by High-F ive cells at $288 \mathrm{~h}(250 \times)$ (microcarriers indicated by black arrows and cellular bridge by transparent arrow). (E) Macroaggregate formation of High-Five cells growing on Cultispher-S microcarriers stained with trypan blue dye at $360 \mathrm{~h}$ (125x) (microcarriers indicated by black arrows and aggregates by white arrow).

$10^{6}$ cells $\mathrm{mL}^{-1}$ (Figure $6 \mathrm{~A}$ and $\mathrm{B}$ ). Further increase of the cell concentration to $8.9 \times 10^{6}$ cells $\mathrm{mL}^{-1}$ did not lead to further increase of the final $\beta$-gal titer (Figure 6B and C). In the latter case, almost two-thirds of the cells were freely suspended at the time of infection and even at 96 h p.i. there were $\sim 2 \times 10^{6}$ viable cells $\mathrm{mL}^{-1}$ in suspension (Figure 7C), implying that infection was not as efficient as at the other two densities (Figure 7A and B). Specific production decreased with increasing time of infection (TOI) for the free cell infections, despite a complete medium change before infection (Table 3 ). When cells were infected on Cultispher-S at $3.4 \times 10^{6}$ cells $\mathrm{mL}^{-1}$ (concentration similar to that of the high-density free cell infection) specific protein production was restored to the low-density free cell infection levels (Table 3). Specific production remained at the same level upon further increase of the infection density on Cultispher-S microcarriers, resulting in a doubling of the volumetric production (Table 3 and Figure $6 \mathrm{~A}$ and $\mathrm{B}$ ). Only at a very highdensity infection of $8.9 \times 10^{6}$ cells $\mathrm{mL}^{-1}$ did specific 

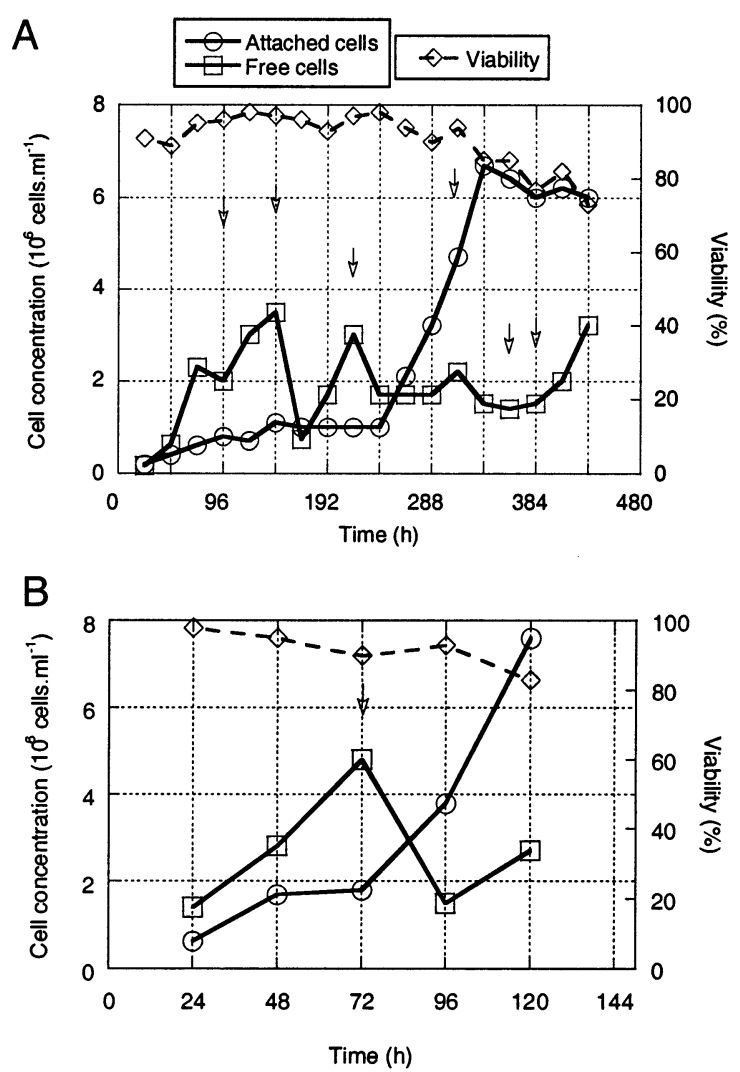

Figure 4. Growth of High-Five cells on Cultispher-S microcarriers. Microcarrier concentration was $1 \mathrm{~g} \mathrm{~L}^{-1}$ and agitation rate was $150 \mathrm{rpm}$. The experiment was performed in 250-mL shake flasks with $50-\mathrm{mL}$ liquid volume in Insect XPRESS medium. F ormed aggregates were (A) disrupted by pipetting (up to $240 \mathrm{~h}$ ) or (B) left undisrupted throughout the cell growth phase in. Arrows indicate the change of half of the medium.

production decrease, reaching the level of the highdensity free cell infection (Figure 6C and Table 3).

Although YPR medium was used for the two highdensity infections, with a glucose content of $10 \mathrm{~g} \mathrm{~L}^{-1}(55.5$ $\mathrm{mM})$ versus $6 \mathrm{~g} \mathrm{~L}^{-1}(33.3 \mathrm{mM})$ of I nsect-XPRESS, glucose was rapidly consumed and completely exhausted by 72 h p.i. (Figure 8). As for the infection at $3.4 \times 10^{6}$ cells $\mathrm{mL}^{-1}$, glucose was exhausted by $96 \mathrm{~h}$ p.i., but at that time almost all of the cells were dead and/or lysed (Figure 8). Although specific glucose consumption rates were almost the same for the infections at 3.4 and $7.2 \times 10^{6}{\text { cells } \mathrm{mL}^{-1}}^{-1}$ there was a $23 \%$ decrease for the $8.9 \times 10^{6}$ cells $\mathrm{mL}^{-1}$ infection (Table 4). Ammonia production, which reflects mainly the consumption of amino acids such as asparagine and glutamine, was higher in the $7.2 \times 10^{6}$ cells $\mathrm{mL}^{-1}$ infection (final concentration of 20.7, 27, and 16.7 $\mathrm{mM}$ for infection densities of 8.9, 7.2, and $3.4 \times 10^{6}$ cells $\mathrm{mL}^{-1}$, respectively; Figure 8 ). Specific ammonia production rate was $4.8 \times 10^{-17} \mathrm{~mol} \mathrm{cell}^{-1} \mathrm{~s}^{-1}$ for the $3.4 \times 10^{6}$ cells $\mathrm{mL}^{-1}$ infection and increased about $43 \%$ and $31 \%$ for the 7.2 and $8.9 \times 10^{6}$ cells $\mathrm{mL}^{-1}$ infections, respectively.

\section{Discussion}

Since their introduction in cell culture practice by van Wezel (27), microcarriers have been a valuable tool for the production of biologicals and the scale-up of commercially viable processes. An important improvement of the system has been the conception of macroporous microcarriers (28), which increased considerably the available surface area for growth per unit volume. We

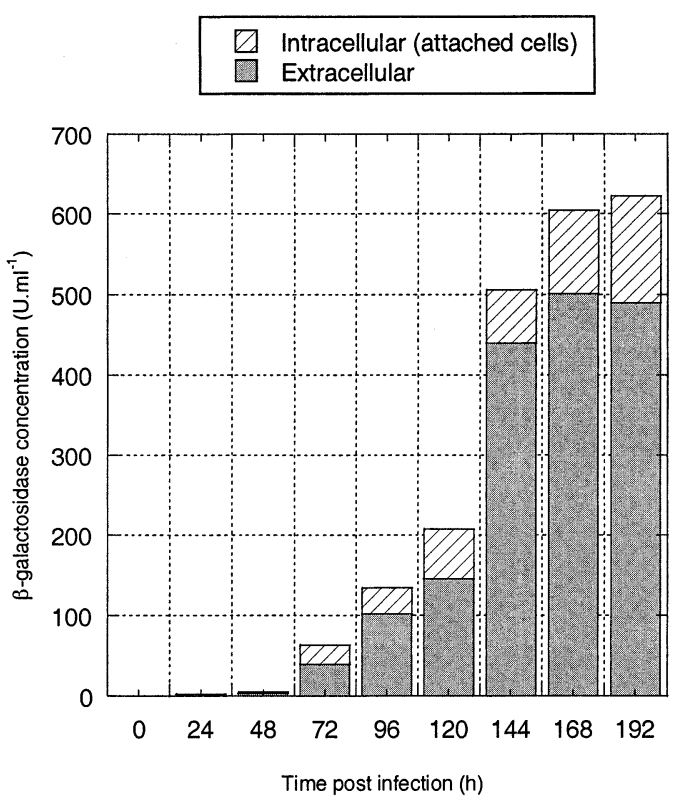

Figure 5. $\beta$-gal production by $\mathrm{Sf}-9$ cells on Fibra-Cel disks. Results are from duplicate $250-\mathrm{mL}$ shake-flasks with $50-\mathrm{mL}$ medium under conditions as in Exp.1 (see Figure 2). Cells were infected at an MOI of 2 and a density of $3.3 \times 10^{6}$ cells $\mathrm{mL}^{-1}$ $\left(6.6 \times 10^{6}\right.$ cells $\left.\mathrm{cm}^{-2}\right)$. Medium was Insect-XPRESS and total medium change was done right before infection. F our disks were used each day for the determination of attached cell concentration and $\beta$-gal production. Values have been corrected to refer to the disks present initially in the flask. $\beta$-gal from free cells was $<1 \%$ of the total at any time and is not presented in the graph.

undertook this study in order to screen several microcarrier types and to find out how the immobilization of insect (lepidopteran) cell lines could affect their growth and protein production after recombinant baculovirus infection.

The unsati sfactory results from compact microcarriers seem to contradict previous reports of good growth of insect cells on compact microcarriers in spinner flask cultures, namely, AA mosquito cells on Cytodex-1 and DE-53 (cylindrical cellulose-based) microcarriers (9) and Tn-5 cells on Cytodex-3 (collagen-coated) microcarriers (12). In the first case, the system had been easily scal ed up to 8-L culture volume. However, this particular cell line is anchorage-prone. As for the second report, the lowest agitation rate capable of keeping microcarriers from settling was used (20-40 rpm) and no value for the maximal cell concentration was reported.

As for the macroporous microcarriers tested, the Cytopore 1 and -2 proved to be rather unsuitable for both Sf-9 and High-Five cells, which displayed virtually no growth even after serum supplementation, thus excluding the likelihood of nutrient limitation. Anchorage-independent cell lines such as $\mathrm{CHO}$ and hybridomas have been successfully cultivated on Cytopore microcarriers and cultures have been scaled up to $20 \mathrm{~L}$ (29). In our hands, $\mathrm{CHO}-\mathrm{K} 1$ cells grew well on Cytopore-2 microcarriers, thus the difficulty to grow insect cells on this type of carrier appears to be cell-line-specific. It is probable that growth inhibition is due to the high porosity of the Cytopore microcarriers and their large pore size $(30 \mu \mathrm{m})$. Cells cannot spread in the interior of the carriers and they rather have several points of contact. This, in turn, can result in stretching of the cell membrane and arrest of cell growth (30). In the case of the Cytopore-2 carriers, the high charge density can be an additional factor for the tight membrane-microcarrier interaction. 


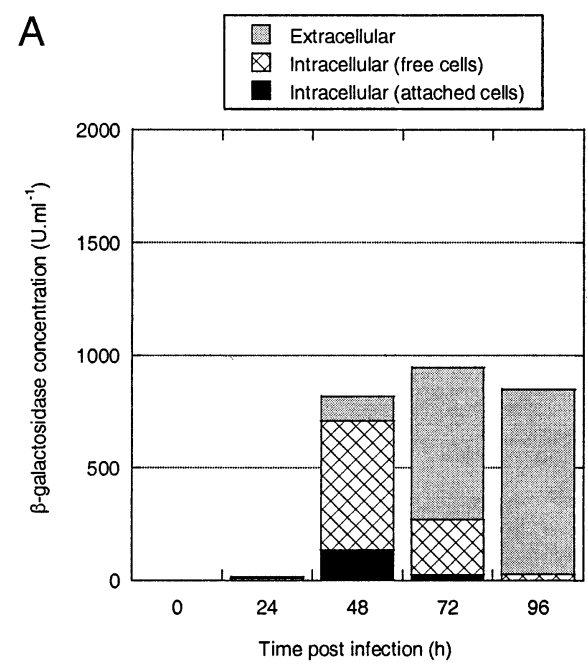

B

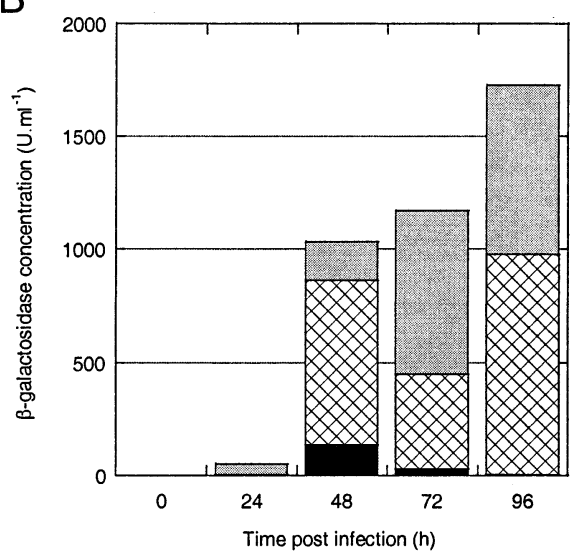

C

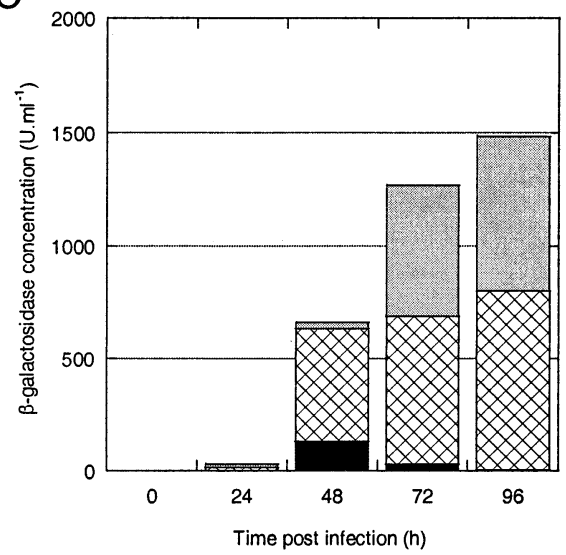

Figure 6. Production of $\beta$-gal by High-Five cells on Cultispher-S infected at (A) $3.4 \times 10^{6}$, (B) $7.2 \times 10^{6}$, and (C) $8.9 \times$ $10^{6}$ cells $\mathrm{mL}^{-1}$. I nfection were performed in duplicate flasks (except for B) with an MOI of 2. Medium was Insect-XPRESS for $A$ and YPR for $B$ and $C$. Agitation rate was set at $150 \mathrm{rpm}$. Total medium change was done right before infection.

The seeding efficiencies of High-Five cells on Cultispher-S microcarriers never exceeded 60\%-65\%. Although the High-F ive cells we use have been adapted to discrete cell growth (19), they come from an aggregation-prone cell line. During inoculation cells tended to form aggregates, and this competed with the migration and attachment inside the microcarrier pores, in agreement with previous observations for mammalian cells $(31,32)$. Low penetration resulted in cell growth mainly on the external surface or within a small distance from the surface (Figure 3C). A similar behavior has been observed
Table 3. Specific Production of Insect Cells Grown in Suspension and on Microcarrier Systems ${ }^{a}$

\begin{tabular}{|c|c|}
\hline mode of culture and infection density & $\begin{array}{c}\text { specific production } \\
\left.\left(\cup \beta \text {-gal ( } 10^{6} \text { cells }\right)^{-1}\right)\end{array}$ \\
\hline $\begin{array}{l}\text { Sf-9 } \\
\text { suspension }\left(1.2 \times 10^{6} \text { cells } \mathrm{mL}^{-1}\right) \\
\text { suspension }\left(2.9 \times 10^{6} \text { cells } \mathrm{mL}^{-1}\right) \\
\text { Fibra-Cel }\left(3.3 \times 10^{6} \text { cells } \mathrm{mL}^{-1}\right)\end{array}$ & $\begin{array}{l}318 \text { (144 h) } \\
164(144 \mathrm{~h}) \\
189(192 \mathrm{~h})\end{array}$ \\
\hline 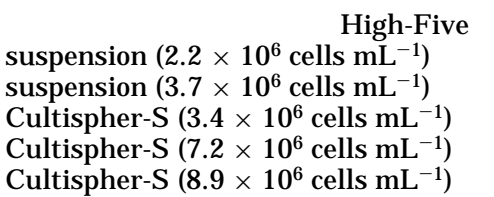 & $\begin{array}{l}246(120 h) \\
156(120 h) \\
225(72 h) \\
240(96 h) \\
166(96 h)\end{array}$ \\
\hline
\end{tabular}

a Specific production was calculated by dividing the maximal total $\beta$-gal concentration for each system by the maximal viable cell concentration. All of the infections were performed with a MOI of 2. Complete change of medium was done before infection. I nsectXPRESS medium was used for all of the infections except for those at 7.2 and $8.9 \times 10^{6}$ cells $\mathrm{mL}^{-1}$, which were performed in YPR medium. For each infection, the time p.i. where the maximal $\beta$-gal concentration was attained is indicated between parentheses.

with HepG2 cells (31). Formation of aggregates and cellular bridges between microcarriers was a precondition for the achievement of high attached cell concentration (Figure 4). The formatted structures often exceeded 500 $\mu \mathrm{m}$ (33). One could expect the presence of a necrotic core due to reduced oxygen and nutrient penetration (34). The size of the macrostructures is much greater than the estimated distance from the periphery where nutrient limitation typically occurs (100-220 $\mu \mathrm{m})$ (35). The absence of such a necrotic center (Figure 3E) can be attributed to the loose connection of microcarriers and aggregates and the presence of some free space inside the macroaggregates, according to the aggregation mechanism proposed previously (33). The exceptional potential of this system to reach high attached cell densities with high viability is clearly illustrated in Figure 4B. Thus it guarantees the rapid growth of cells to high densities $\left(>10 \times 10^{6}\right.$ cells $\left.\mathrm{mL}^{-1}\right)$ and facilitates baculovirus infection and protein production (see below).

Both cell lines were successfully immobilized on FibraCel disks in shake-flask cultures. Although this support is primarily used in fixed bed configurations (36), it had been utilized at least once in suspension culture (37). Our results show that insect cells can grow to high densities inside the Fibra-Cel disks even in agitated systems. The predicted initial cell densities are somewhat lower than the ones calculated on the basis of the seeding density and efficiency, especially in the case of Exp.1 for Sf-9 cells. Nevertheless, the other two parameters ( $\mu$ and $\beta$ ) give valuable insights into the growth patterns of the two cell lines on the disks. I ncrease of agitation rate from 100 to 150 rpm did not affect significantly specific growth rate and maximum obtained density for the same cell line (Figure 2; logistic equation parameters in Table 2). Although High-Five cells grew faster than Sf-9 (higher $\mu$, Table 2) they eventually reached lower final densities (5.2 and $5.7 \times 10^{6}$ cells $\mathrm{cm}^{-2}$ versus 8.3 and $7.4 \times 10^{6}$ cells $\mathrm{cm}^{-2}$ for Exp.1 and Exp.2, calculated as the inverse of the $\beta$ term). The good fitting of the experimental values by the logistic equation suggests that both High-Five and Sf-9 cell growth may be inhibited beyond a certain cell density. Extensive cell leakage from the disks is unlikely as increase in free cell concentration was rather due to proliferation of nonattached cells (22). The profile of cell growth as seen in Figure $3 \mathrm{~B}$ is in contrast with previous reports for insect (13) and MRC-5 cells (38), where cells grew along the fibers of these carriers. The different 
A

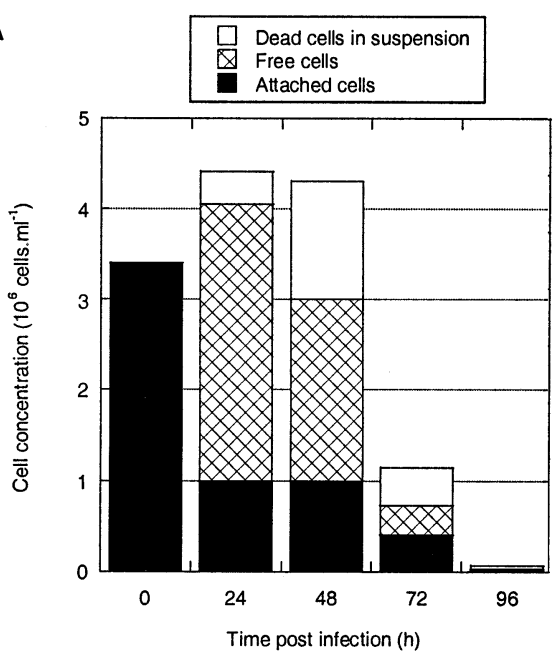

B

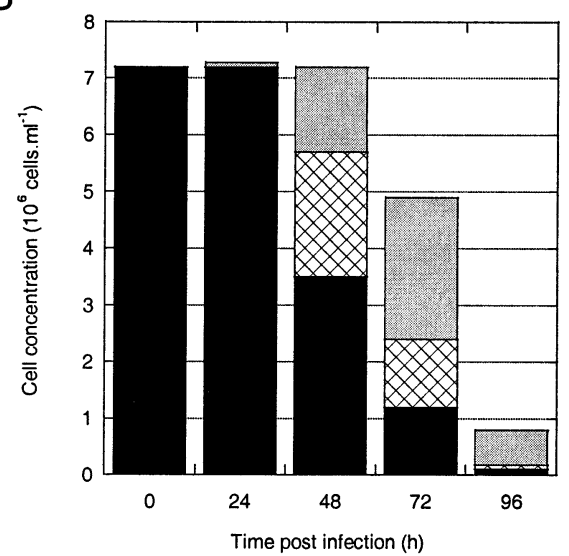

C

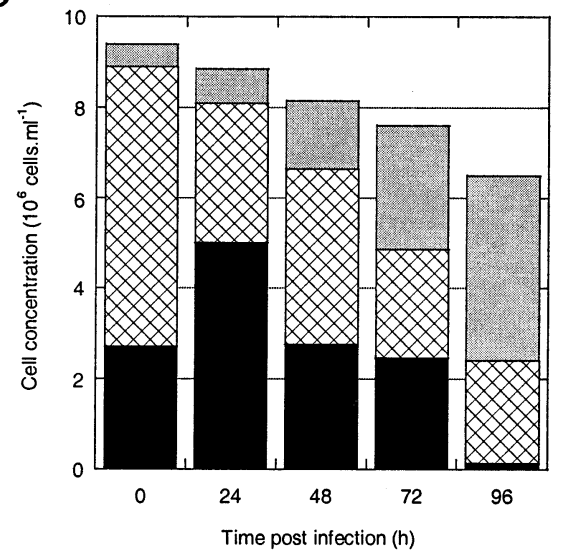

Figure 7. State of cells after infection of High-Five cells on Cultispher-S microcarriers at initial cell concentration of (A) 3.4 $\times 10^{6}$, (B) $7.2 \times 10^{6}$, and (C) $8.9 \times 10^{6}$ cells $\mathrm{mL}^{-1}$. Infection conditions are the same as in Figure 6.

growth patterns may be due to the total absence of serum at every step (fiber treatment, inoculation, and growth) in our case, contrary to the other reports where seeding and cell growth was in serum-supplemented media. The presence of serum proteins, such as fibronectin, could have favored the strong attachment of cells along the fibers and their growth as cell layer(s). This is further supported by our recent results from $\mathrm{CHO}$ cell growth on Fibra-Cel, where culture in the presence or absence of serum resulted in different growth patterns on the fibers ( $F$. Verhoeye, unpublished data). Thus, pretreatment of disks with serum-containing medium might

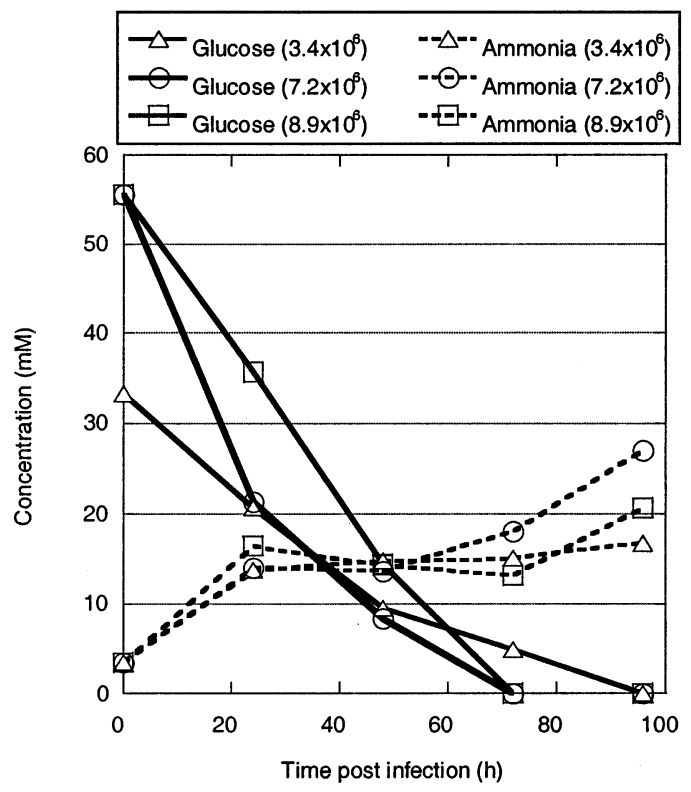

Figure 8. Glucose consumption and ammonia production profiles for infected High-Five cells on Cultispher-S microcarriers for three infection densities. Infection conditions are the same as in Figure 6.

Table 4. Metabolic Parameters for Infected High-Five Cells on Cultispher-S Microcarriers

\begin{tabular}{ccc}
\hline $\begin{array}{c}\text { viable cell density } \\
\text { at infection } \\
\left(10^{6} \text { cells } \mathrm{L}^{-1}\right)\end{array}$ & $\begin{array}{c}\text { specific glucose } \\
\text { consumption rate } \\
\left(10^{-17} \mathrm{~mol} \mathrm{cell}^{-1} \mathrm{~s}^{-1}\right)\end{array}$ & $\begin{array}{c}\text { specific ammonia } \\
\text { production rate } \\
\left(10^{-17} \text { mol cell }^{-1} \mathrm{~s}^{-1}\right)\end{array}$ \\
\hline 3.4 & -3.9 & 4.8 \\
7.2 & -3.8 & 6.9 \\
8.9 & -3.0 & 6.3
\end{tabular}

promote the attachment of insect cells on the fibers and increase the available area for growth. Our results compare favorably with previously published values. Sf21 cells growing in a packed bed reactor ( $3 \mathrm{~g}$ of FibraCel in a 50-mL volume) reached a cell density of $6 \times 10^{6}$ cells $\mathrm{mL}^{-1}$ of packed carrier or $1 \times 10^{8}$ cells g ${ }^{-1}$ of FibraCel (13). This value is inferior to our own maximal attained densities of $4 \times 10^{8}\left(8 \times 10^{6}\right.$ cells cm$\left.~^{-2}\right)$ and 2.9 $\times 10^{8}$ cells g ${ }^{-1}\left(5.8 \times 10^{6}\right.$ cells $\left.\mathrm{cm}^{-2}\right)$ for Sf-9 and HighFive cells, respectively (F igure 2, taking into account that $1 \mathrm{~g}$ of Fibra-Cel has $50 \mathrm{~cm}^{2}$ of projected area). Similarly, these maximal densities are much higher than that obtained from Sf-9 cells immobilized on sheets of nonwoven polyester fibers in a 2-L bioreactor $\left(2.47 \times 10^{6}\right.$ cells $\mathrm{cm}^{-2}$ of gross surface area or $1.23 \times 10^{6}$ cells $\mathrm{cm}^{-2}$ of projected area) (39).

Infection of Sf-9 cells on Fibra-Cel disks at a density of $3.3 \times 10^{6}$ cells $\mathrm{mL}^{-1}\left(6.6 \times 10^{6}\right.$ cells $\left.\mathrm{cm}^{-2}\right)$ resulted in a rather prolonged $\beta$-gal production (Figure 5 ) compared to free cell infections where maximal $\beta$-gal concentration is reached within $96-120 \mathrm{~h}$ (unpublished results). Although the MOI was 2, only a small fraction of cells (most probably cells at the disk surface) appeared to be infected initially as indicated by the very low total $\beta$-gal content (F igure 5). The cells in the interior of the disks are most probably infected with a high MOI by the virus produced from the first cycle. This would explain the delayed $\beta$-gal production and the abrupt increase of $\beta$-gal concentration between 120 and $144 \mathrm{~h}$ (Figure 5). Fluorescent $\beta$-gal substrates (40) or GFP-expressing bacul ovirus $(41,42)$ could be very useful tools to visualize the progression of virus infection within the disks. Even though production of $\beta$-gal was delayed, the specific production was similar 
to that of a free cell infection at about the same viable cell density (Table 3).

Cell behavior and $\beta$-gal production profile were markedly different during infection of High-Five cells on Cultispher-S microcarriers compared to the Sf-9 infection on Fibra-Cel disks (Figures 6 and 7). Examination of Figure 7 points to an efficient infection that led rapidly to aggregate dissolution and subsequent cell Iysis. Despite the fact that the cells were in the form of macroaggregates at the time of infection, the system was quickly switched to single-cell suspension after infection. As cellular oxygen uptake rate (OUR) transiently increases after infection (40), dissolution of aggregates helps to avoid oxygen limitation that could otherwise occur in their center. The differences seen in Fibra-Cel and Cultispher-S infections can be partly attributed to different cell surface compositions. These differences appear to be due to the two different cell lines used (Sf-9 for Fibra-Cel and High-Five for Cultispher-S) rather than to different culture conditions. Sf- 9 and High-Five cells have different membrane compositions, in terms of phospholipids and fatty acids (43). High-Five cells were found to be more prolific in terms of $\beta$-gal and SEAP production $(44,45)$. Passage number can also play a role in infection susceptibility, even for the same cell line. In our case, we think that virus diffusion may have played a more important role in the efficiency of the two infections. In the Fibra-Cel infection, diffusion of the virus may have been limited from the outer cell layer, whereas in the Cultispher-S infection baculovirus may have diffused more easily in the macroaggregates as a result of their loose nature, thus infecting more cells in the first place. In addition, cells are less likely to be released from the Fibra-Cel disks than from the dissolved Cultispher-S macroaggregates after baculovirus infection.

Comparison of the specific $\beta$-gal productions for the Cultispher-S infections with suspension culture infections gave unexpected results. Remarkably, the specific production of the infections at 3.4 and $7.2 \times 10^{6}$ cells $\mathrm{mL}^{-1}$ was about the same as that for a single-cell infection at $2.2 \times 10^{6}$ cells $\mathrm{mL}^{-1}$ (Table 3 ). This brought about a dramatic increase in volumetric production, which for the latter density was $1730 \mathrm{U} \mathrm{mL}-1$, one of the highest productions ever reported for insect cells. Similar results were also obtained with a SEAP-expressing baculovirus (33). The maintenance of high specific productions at very high infection densities strongly suggest that the socalled "cell density effect" can be overcome by medium change, in accordance with recent reports (5). N evertheless, complete medium change can be only one of the reasons accounting for the restoration of specific production. It was recently suggested that cell cycle progression of insect cell cultures can have a significant effect on protein productivity (46) and that cell cycle can be arrested following baculovirus infection (47). Mammalian cells growing on microcarriers have been shown to be mainly in the $G_{0}$ and $G_{1}$ phases (48). Therefore, if the High-Five cell cycle is synchronized in $G_{0}$ and $G_{1}$ as a result of the cells' immobilization, they may be more easily infected by the baculovirus and probably more productive (49). Unfortunately, the only existing (and few) data come from Sf-9 infections $(46,49)$, making imperative the need for thorough studies of High-Five cell cycle and its relation to protein production. The exhaustion of glucose by $72 \mathrm{~h}$ p.i. for the two higher densities (Figure 8) and the unusually high ammonia production rates (Table 4) compared to previously reported values (16) point to a very active energetic metabolism during infection. As it has been pointed out before, insect cell metabolism is a substrate-concentration-dependent overflow metabolism (50). Thus, the high glucose and glutamine levels initially present in the YPR medium may have resulted in increased glycolysis and glutaminolysis fluxes. Ammonia production rate was similar to those of uninfected High-Five suspension cultures $(16,19)$, but it was severalfold higher compared to production rates of infected High-Five cells (16).

Overall, our results show that anchorage-independent cell lines, such as High-Five and Sf-9, can be successfully cultivated on macroporous microcarriers and Fibra-Cel disks. These supports provide a microenvironment (6) that at the same time permits the entrapment or attachment of cells and their growth to high viable cell densities. The infection of our immobilized cells at high densities (the highest reported in the literature for HighFive cells, to our knowledge) led to el evated vol umetric productions thanks to constant cell-specific production levels.

\section{Acknowledgment}

The support of a fellowship from FDS (Scientifc Development Fund, Université catholique de Louvain, Belgium) to L.I. is gratefully acknowledged. We are thankful to Axel J acobs for help with the confocal microscopy and to Geneviève Schmitz-Drevillon for technical assistance.

\section{References and Notes}

(1) Birch, J . R.; Froud, S. J . Mammalian cell culture systems for recombinant protein production. Biologicals 1994, 22, 127-133

(2) Taticek, R. A.; Lee, C. W. T.; Shuler, M. L. Large-scale insect and plant cell culture. Curr. Opin. Biotechnol. 1994, 5, 165174.

(3) Hu, W.-S.; Aunins, J . G. Large-scale mammalian cell culture. Curr. Opin. Biotechnol. 1997, 8, 148-153.

(4) Agathos, S. N. I nsect cell bioreactors. Cytotechnol ogy 1996, 20, 173-189.

(5) Chico, E.; J äger, V. Perfusion culture of baculovirus-infected BTI-Tn-5B 1-4 insect cells: A method to restore cell-specific $\beta$-trace glycoprotein productivity at high cell density. Biotechnol. Bioeng. 2000, 70, 574-586.

(6) Vournakis, J . N.; Runstadler, P. W. Microenvironment: The key to improved cell culture processes. Bio/ Technol ogy 1989, 7, 143-145.

(7) Griffiths, J. B.; Looby, D.; Racher, A. J . Maximisation of perfusion systems and process comparison with batch-type cultures. Maximisation of perfusion cultures. Cytotechnology 1992, 9, 3-9.

(8) Chu, L.; Robinson, D. K. Industrial choices for protein production by large-scale cell culture. Curr. Opin. Biotechnol. 2001, 12, 180-187.

(9) Lazar, A.; Silberstein, L.; Reuveny, S.; Mizrahi, A. Microcarriers as a culturing system of insect cells and insect viruses. Dev. Biol. Stand. 1987, 66, 315-323.

(10) Agathos, S. N.; J eong, Y.-H.; Venkat, K. Growth kinetics of free and immobilized insect cell cultures. Ann. N.Y. Acad. Sci. 1990, 589, 372-398.

(11) Chung, I. S.; Taticek, R. A.; Shuler, M. L. Production of human alkaline phosphatase, a secreted, glycosylated protein, from a baculovirus expression system and the attachmentdependent cell line Trichoplusia ni BTI-Tn 5B1-4 using a split-flow, air-lift bioreactor. Biotechnol . Prog. 1993, 9, 675678.

(12) Wickham, T. J .; Nemerow, G. R. Optimization of growth methods and recombinant protein production in BTI-Tn5B1-4 insect cells using the baculovirus expression system. Biotechnol. Prog. 1993, 9, 25-30.

(13) Kompier, R.; Kislev, N.; Segal, I.; Kadouri, A. Use of a stationary bed reactor and serum-free medium for the 
production of recombinant proteins in insect cells. Enzyme Microb. Technol. 1991, 13, 822-827.

(14) Saarinen, M. A.; Troutner, K. A.; Gladden, S. G.; MitchellLogean, C. M.; Murhammer, D. W. Recombinant protein synthesis in Trichoplusia ni BTI-TN-5B1-4 insect cell aggregates. Biotechnol. Bioeng. 1999, 63, 612-617.

(15) Wu, J .; King, G.; Daugulis, A. J .; Faulkner, P.; Bone, D. H.; Goosen, M. F. A. Adaptation of insect cells to suspension culture. J. Ferment. Bioeng. 1990, 70, 90-93.

(16) Rhiel, M.; Mitchell-Logean, C. M.; Murhammer, D. W. Comparison of Trichoplusia ni BTI-Tn-5B 1-4 (High Five) and Spodoptera frugiperda Sf-9 insect cell line metabolism in suspension cultures. Biotechnol. Bi oeng. 1997, 55, 909-920.

(17) Taticek, R. A.; McKenna, K. A.; Granados, R. R.; Shuler, M. L. Rapid initiation of suspension cultures of Trichoplusia ni insect cells (TN 5B-1-4) using heparin. Biotechnol. Tech. 1997, 11, 237-240.

(18) Dee, K. U.; Shuler, M. L.; Wood, H. A. Inducing single-cell suspension of BTI-TN5B1-4 insect cells: I. The use of sulfated polyanions to prevent cell aggregation and enhance recombinant protein production. Bi otechnol. Bi oeng. 1997, 54 191-205.

(19) I konomou, L.; Bastin, G.; Schneider, Y.-J .; Agathos, S. N . Design of an efficient medium for insect cell growth and recombinant protein production. In Vitro Cell. Dev. Biol.Animal 2001, 37, 549-559.

(20) O'Reilly, D. R.; Miller, L. K.; Luckow, V. A. Baculovirus Expression Vectors: A Laboratory Manual; W. H. Freeman and Company: New York, 1992.

(21) Miller, J. H. Assay of $\beta$-galactosidase. In Experiments in Molecular Genetics; Cold Spring Harbor Laboratory Press: New York, 1972; pp 352-355.

(22) I konomou, L.; Bastin, G.; Schneider, Y.-J .; Agathos, S. N Growth on microcarriers and nutritional needs of high-density insect cell cultures. In Animal Cell Technology: Products from Cells, Cells as Products; Bernard, A., Griffiths, B., Noé, W. Wurm, F., Eds.; Kluwer Academic Publishers: Dordrecht, 1999; pp 371-373.

(23) Bailey, J . E.; Ollis, D. F. Biochemical Engineering F undamentals, 2nd ed.; McGraw-Hill chemical engineering series; McGraw-Hill: New York, 1986.

(24) Hensler, W.; Singh, V.; Agathos, S. N. Sf-9 insect cell growth and $\beta$-galactosidase production in serum and serumfree media. Ann. N.Y. Acad. Sci. 1994, 745, 149-166.

(25) Schneider, Y.-J . Optimisation of hybridoma cell growth and monocl onal antibody secretion in a chemically defined, serumand protein-free culture medium. J . I mmunol. M ethods 1989, $116,65-77$.

(26) Reiter, M.; Hohenwarter, O.; Gaida, T.; Zach, N.; Schmatz, C.; Blüml, G.; Weigang, F.; Nilsson, K.; Katinger, H. The use of macroporous gelatin carriers for the cultivation of mammalian cells in fluidised bed reactors. Cytotechnology 1990, 3, 271-277.

(27) van Wezel, A. L. Growth of cell strains and primary cells on micro-carriers in homogeneous culture. Nature 1967, 216, 64-65.

(28) Nilsson, K.; Buzsaky, F.; M osbach, K. Growth of anchoragedependent cells on macroporous microcarriers. Bio/ Technology 1986, 4, 989-990.

(29) Xiao, C.; Huang, Z.; Li, W.; Hu, X.; Qu, W.; Gao, L.; Liu, G. High density and scale-up cultivation of recombinant $\mathrm{CHO}$ cell line and hybridomas with porous microcarrier Cytopore. Cytotechnology 1999, 30, 143-147.

(30) Reuveny, S. Microcarrier culture systems. In Large-Scale Mammalian Cell Culture Technology; Lubiniecki, A. S., Ed.; Marcel-Dekker: New York, 1990; pp 271-341.

(31) Lim, H.-S.; Han, B.-K.; Peshwa, M. V.; Hu, W.-S. Spatial distribution of mammalian cells grown on macroporous microcarriers with improved attachment kinetics. Biotechnol. Prog. 1992, 8, 486-493.

(32) Ng, Y. C.; Berry, J . M.; Butler, M. Optimization of physical parameters for cell attachment and growth on macroporous mi crocarriers. Biotechnol. Bioeng. 1996, 50, 627-635.
(33) Drugmand, J .-C.; I konomou, L.; Schneider, Y.-J .; Agathos, S. N. Growth of High-Five cells on Cultispher-S microcarriers. In Animal Cell Technol ogy: From Target to Market; LindnerOlsson, E., Chatzissavidou, N., Lüllau, E., Eds.; Kluwer Academic Publishers: Dordrecht, 2001; pp 332-334.

(34) Preissmann, A.; Wiesmann, R.; Buchholz, R.; Werner, R. G.; N oé, W. I nvesti gations on oxygen limitations of adherent cells growing on macroporous microcarriers. Cytotechnology 1997, 24, 121-134.

(35) Cahn, F. Biomaterials aspects of porous microcarriers for animal cell culture. Trends Biotechnol. 1990, 8, 131-136.

(36) Wang, G.; Zhang, W.; J acklin, C.; F reedman, D.; Eppstein, D.; Kadouri, A. Modified CelliGen-packed bed bioreactors for hybridoma cell cultures. Cytotechnology 1992, 9, 41-49.

(37) Racher, A. J .; Fooks, A. R.; Griffiths, J . B. Culture of 293 cells in different culture systems: cell growth and recombinant adenovirus production. Biotechnol. Tech. 1995, 9, 169174.

(38) Petti, S. A.; Lages, A. C.; Sussman, M. V. Threedimensional mammalian cell growth on nonwoven polyester fabric disks. Biotechnol. Prog. 1994, 10, 548-550.

(39) Archambault, J .; Robert, J .; Tom, L. Culture of immobilized insect cells. Bioprocess Eng. 1994, 11, 189-197.

(40) Hensler, W. T.; Agathos, S. N. Evaluation of monitoring approaches and effects of culture conditions on recombinant protein production in baculovirus-infected insect cells. Cytotechnology 1994, 15, 177-186.

(41) Cha, H. J .; Pham, M.-Q.; Rao, G.; Bentley, W. E. Expression of green fluorescent protein in insect larvae and its application for heterologous protein production. Biotechnol. Bioeng. 1997, 56, 239-247.

(42) Barrett, J. W.; Brownwright, A. J .; Primavera, M. J .; Palli, S. R. Studies of the nucleopolyhedrovirus infection process in insects by using the green fluorescence protein as a reporter. J . Virol. 1998, 72, 3377-3382.

(43) Marheineke, K.; Grünewald, S.; Christie, W.; Reiländer, $\mathrm{H}$. Lipid composition of Spodoptera frugiperda (Sf-9) and Trichoplusia ni (Tn) insect cells used for baculovirus infection. FEBS Lett. 1998, 441, 49-52.

(44) Davis, T. R.; Wickham, T. J .; McKenna, K. A.; Granados, R. R.; Shuler, M. L.; Wood, H. A. Comparative recombinant protein production of eight insect cell lines. In Vitro Cell. Dev. Biol. 1993, 29, 388-390.

(45) Wickham, T. J .; Davis, T.; Granados, R. R.; Shuler, M. L.; Wood, H. A. Screening of insect cell lines for the production of recombinant proteins and infectious virus in the baculovirus expression system. Biotechnol. Prog. 1992, 8, 391-396.

(46) Doverskog, M.; Bertram, E.; Ljunggren, J .; Öhman, L.; Sennerstam, R.; Häggström, L. Cell cycle progression in serum-free cultures of Sf-9 insect cells: modulation by conditioned medium factors and implications for prol iferation and productivity. Biotechnol. Prog. 2000, 16, 837-846.

(47) Braunagel, S. C.; Parr, R.; Belyavskyi, M.; Summers, M. D. Autographa californica nucleopolyhedrovirus infection results in Sf-9 cell cycle arrest at G2/M phase. Virology $\mathbf{1 9 9 8}$ 244, 195-211.

(48) Hawboldt, K. A.; Linardos, T. I.; Kalogerakis, N.; Behie, L. A. Cell cycle dynamics of microcarrier cultures. J . Biotechnol. 1994, 34, 133-147.

(49) Saito, T.; Dojima, T.; Toriyama, M.; Park, E. Y. The effect of cell cycle on GFPuv gene expression in the baculovirus expression system. J . Biotechnol. 2002, 93, 121-129.

(50) Doverskog, M.; Ljunggren, J .; Öhman, L.; Häggström, L. Physiology of cultured animal cells. J . Biotechnol. 1997, 59, 103-115.

Accepted for publication J uly 18, 2002.

BP0255107 